\title{
Anti-bacterial activities of silver nanoparticles synthesized from plant leaf extract of Abutilon indicum (L.) Sweet
}

\author{
M. Prathap · A. Alagesan • B. D. Ranjitha Kumari
}

Received: 5 February 2014/ Accepted: 1 May 2014/Published online: 5 June 2014

(c) The Author(s) 2014. This article is published with open access at Springerlink.com

\begin{abstract}
Abutilon indicum (L.) Sweet is an Asian phytomedicinal plant and it has hypoglycemic and anti-bacterial activities. The nano silver was successfully synthesized from leaf extract using A. indicum (L.) Sweet. Nitrate reductase enzyme or other extra cellular proteins released from leaf extract involve in reduction of nitrate and formation of silver ions occurs. These proteins or enzymes act as template for the silver nucleation sites for the formation of silver nanocrystals and also act as capping agents (peptides or proteins) which control the size and shape of silver nanoparticles. FTIR reveals that protein molecules can be bound to silver nanoparticles and XRD result confirmed crystal structure of nanoparticles. On the basis of our results, extract of $A$. indicum (L.) Sweet leaf protein molecules plays a vital role in reducing and capping of silver nanoparticles at $50 \mu \mathrm{l}$ concentrations which act as anti-bacterial agent to control pathogenic microorganisms of Klebsiella pneumonia, Salmonella typhi, Bacillus subtilis, and Proteus vulgaris.
\end{abstract}

Keywords Nano silver - Abutilon indicum - XRD . FT-IR · Anti-bacterial activity

\section{Introduction}

The plant-mediated synthesis is a rapid, flexible and suitable process for large-scale production of nanoparticles. Nowadays, plant parts like seed [1], leaf [2, 3], bark [4], stem [3, 5] and fruit [6] extracts have been effectively used for synthesis of nanoparticles. Among nanoparticles, silver nanoparticles

M. Prathap - A. Alagesan - B. D. Ranjitha Kumari ( $\square)$ Department of Plant Science, Bharathidasan University, Tiruchirappalli 620024, Tamil Nadu, India e-mail: ranjithakumari2004@yahoo.co.in have been used enormously due to their potent anti-bacterial [7], anti-fungal activity [8]. Cassia auriculata is a common plant, profoundly used as anti-pyretic, hepatoprotective, anti-diabetic, anti-hyperglycemic, conjunctivitis, ulcers, leprosy, skin and liver diseases. Although there are several reports on synthesis of silver nanoparticles from plants and its anti-microbial activity [9]. Owing to the excellent antimicrobial properties, the silver nanoparticles have been widely used in food packaging [10], preservation [11], cosmetics [12], and medicine [13].

Silver nanoparticles have found tremendous applications in the field of high sensitivity bio-molecular detection, diagnostics, catalysis and micro-electronics. A number of approaches are available for the synthesis of silver nanoparticles for example, reduction in solutions, chemical and photochemical reactions in reverse micelles, thermal decomposition of silver compounds, radiation assisted, electro chemical, sono-chemical, microwave-assisted process, and recently via green chemistry route.

Silver nanoparticles were synthesized using dried areca nut (Areca catechu). The microwave exposed aqueous areca nut powder when treated with the aqueous silver salt solution yielded irregular shaped silver nanoparticles. The understanding of capping of biological moiety is derived from Fourier transform infrared spectroscopy and the thermo gravimetric analysis [14].

Green silver nanoparticles (AgNPs) have been synthesized using various natural products like Azadirachta indica [15], Glycine max [16], Cinnamon zeylanicum [17], Camellia sinensi [18] Peel extract of Pomegranate [19] and Callicarpa maingayi stem bark extract [20]. However, there is still a need for economic, commercially viable as well environmentally clean route to synthesize AgNPs. Green synthesis provides advancement over chemical and physical method as it is cost effective, environment 
friendly, easily scaled up for large-scale synthesis and further there is no need to use high pressure, energy, temperature and toxic chemicals. The morphology and crystalline phase of the NPs were determined from UV-Vis spectroscopy, Fourier transform infrared (FT-IR) spectroscopy and X-ray diffraction (XRD) spectra.

The development of new resistant strains of bacteria to current antibiotics has become a serious problem in public health; therefore, there is a strong incentive to develop new bactericides. Silver has long been known to exhibit a strong toxicity to a wide range of microorganisms for these reason silver-based compounds have been used extensively in many bactericidal applications. Silver compounds have also been used in the medical field to treat burns and a variety of infections. Jiang et al. [21] reported that the $\mathrm{Ag}$ has long been recognized as having an inhibitory effect toward many bacterial strains and microorganisms commonly present in medical and industrial processes. AgNPs are reported to possess anti-fungal [22], anti-inflammatory [23], and anti-viral activity [24].

In the present study, we report the synthesis of silver nanoparticles reducing the silver ions present in the solution of silver nitrate by the cell-free aqueous leaf extract of Abutilon indicum (L.) Sweet and their role as high antimicrobial activity.

\section{Materials and methods}

Biosynthesis of silver nanoparticles

Biosynthesis of silver nanoparticles was done according to the method of Song and Kim [25]. A. indicum (L.) Sweet plant leaves were collected from botanical garden of our Department, Tiruchirappalli-24, Tamilnadu, India and air dried for 10 days and then was kept in the hot air oven at $60{ }^{\circ} \mathrm{C}$ for 24-48 $\mathrm{h}$. The leaves were ground to a fine powder. $1 \mathrm{mM}$ silver nitrate solution was added to plant extract to make up a final volume of $200 \mathrm{ml}$ and centrifuged at $18,000 \mathrm{rpm}$ for $25 \mathrm{~min}$. The collected pellets were stored at $4{ }^{\circ} \mathrm{C}$. The supernatant was heated at $50-95{ }^{\circ} \mathrm{C}$. A change in the color of solution was observed during the heating process.

Anti-bacterial activity

A loop full of strain was inoculated in $25 \mathrm{ml}$ of nutrient broth in a conical flask and incubated at room temperature on a rotary shaker for $24 \mathrm{~h}$ for the growth of bacteria. Nutrient agar medium (Himedia) was used for the anti-bacterial susceptibility study. The bacterial assay was performed by agar well diffusion method [26]. The media were poured into Petri dishes. After the media get solidified, the $60 \mu \mathrm{l}$ of test strains was spreaded using L-rod and the well was made in the plates with the help of a cup-borer $(8.5 \mathrm{~mm})$. The well was filled with $50 \mu \mathrm{l}$ of the synthesized AgNPs from plant extract and then plates were incubated over night at $37{ }^{\circ} \mathrm{C}$. The bacterial growth was determined by measuring the diameter of the zone of inhibition. The experiment was done three times and the mean values were presented. The sterile disc was maintained as control for each bacterial strain.

Characterization of nanoparticles

UV spectroscopy analysis

About $5 \mathrm{mg}$ of the deposit of silver NPs was sonicated in $10 \mathrm{ml}$ water and the suspended nanoparticles were immediately measured in UV-visible Spectrophotometer (50 ANALYTIKJENA).

\section{FT-IR spectroscopy analysis}

The silver nanoparticles were analyzed by FT-IR spectroscopy. The FT-IR spectrum was taken in the mid IR region of $400-4,000 \mathrm{~cm}^{-1}$. The spectrum was recorded using Attenuated Total Reflectance (ATR) technique. The sample was directly placed in the zinc selenide crystal and the spectrum was recorded in the transmittance mode.

\section{XRD analysis}

The silver nanoparticles were analyzed by X-ray diffractometer (X'pert PRO PAN analyzer) with Syn Master 793 software to identify the nanoparticles product. The XRD pattern was recorded using computer controlled XRDsystem, JEOL, and Model: JPX-8030 with CuK radiation (Ni filtered $=13418 \mathrm{Ao}$ ) at the range of $40 \mathrm{kV}, 20 \AA$. The 'peak search' and 'search match' program built in software (syn master 7935) was used to identify the peak table and ultimately for the identification of XRD peak. XRD analysis was carried out in Central Electrochemical Research Institute (CERI), Karaikudi.

\section{Particle size analysis}

$10 \mathrm{mg}$ of synthesized nanoparticles were taken and suspended with distilled water. Then this medium was characterized by particle size analyzer.

\section{Results and discussion}

Biosynthesis of silver nanoparticles

When the leaf extract incubated with silver nitrate, it was turned pale brown in color (Fig. 1) because of reduction 


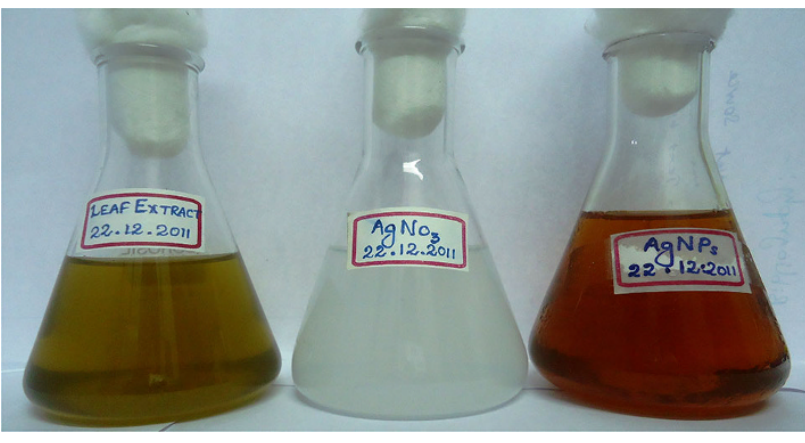

Fig. 1 Biosynthesis of silver nanoparticles using plant leaf extract of A. indicum (L.) Sweet

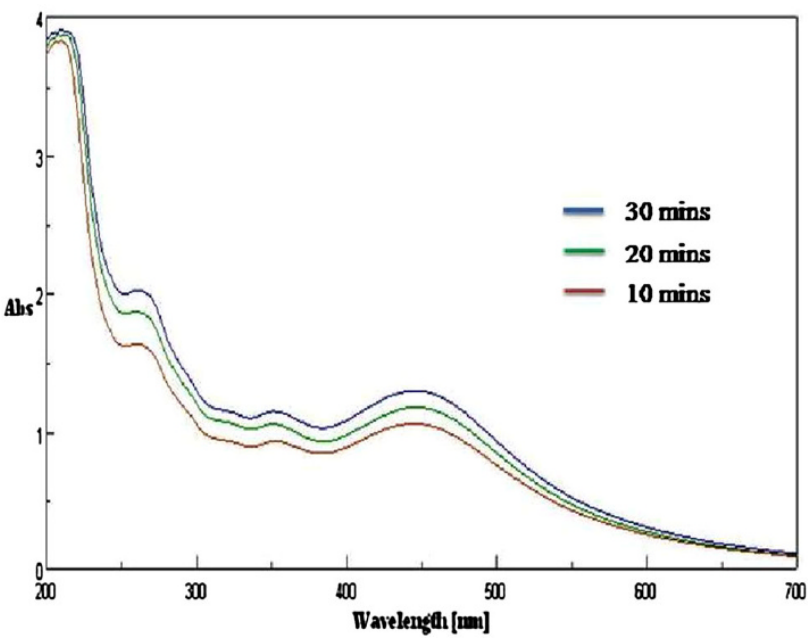

Fig. 2 UV-visible spectrum of synthesized silver nanoparticles reaction appeared in the biological synthesis process. The confirmations of these nanoparticles are as followed by different characterizations.

\section{UV spectroscopy analysis}

UV-visible spectra of silver nanoparticles were taken in water medium. The strong absorption peaks at $435 \mathrm{~nm}$ are associated with the silver nanoparticles (Fig. 2). It can be assumed that leaf protein acts as a template for the synthesis of silver nanoparticles and as well as stabilizing of nanoparticles. The formation of AgNPs was followed by measuring the surface-plasmon resonance (SPR) of the A. indicum (L.) Sweet and Ag/A. indicum (L.) Sweet emulsions over the wavelength range of 200-700 nm (Fig. 2). The SPR bands are influenced by the size, shape, morphology, composition and dielectric environment of the prepared nanoparticles [27]. Previous studies have shown that the spherical AgNPs contribute to the absorption bands at around $400-420 \mathrm{~nm}$ in the UV-visible spectra [27, 28]. These absorption bands were assumed to correspond to the AgNP's extra-fine nature, with relatively small size.

\section{FT-IR spectroscopy analysis}

FT-IR spectrum recorded from the film of silver nanoparticles formed after $24 \mathrm{~h}$ of incubation with the protein molecules. The bands seen at 3,280 and $2,924 \mathrm{~cm}^{-1}$ were assigned to the stretching vibrations of primary and

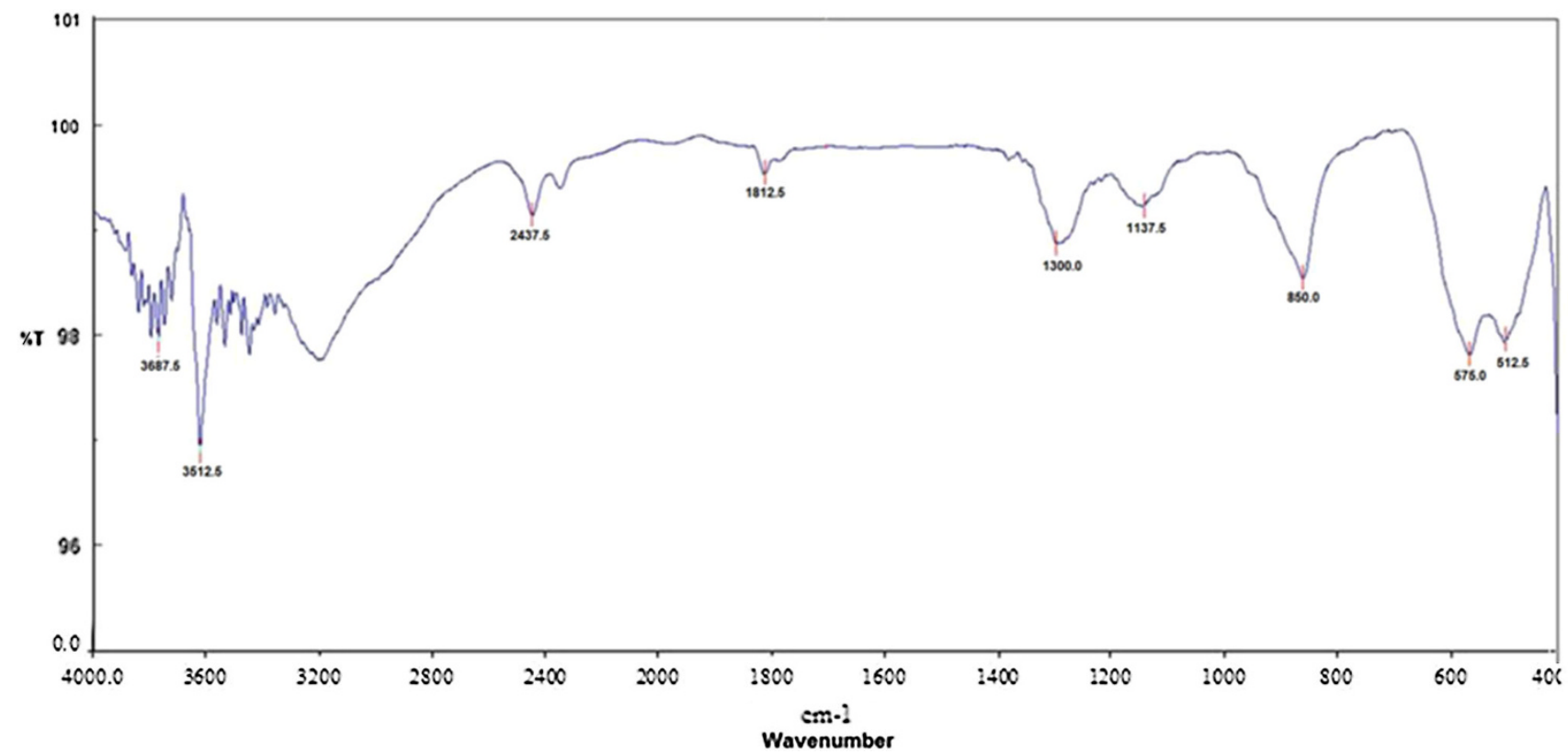

Fig. 3 FT-IR analysis 
secondary amines, respectively. The corresponding bending vibrations were seen at 1,651 and $1,548 \mathrm{~cm}^{-1}$, respectively. The two bands observed at 1,379 and $1,033 \mathrm{~cm}^{-1}$ can be assigned to the $\mathrm{C}-\mathrm{N}$ stretching vibrations of aromatic and aliphatic amines, respectively (Fig. 3). The presence of protein as a stabilizing agent which surrounds the silver nanoparticles. It is reported earlier that proteins can bind to nanoparticles either through free mine groups or cysteine residues in the proteins and via the electrostatic attraction of negatively charged carboxylate groups in enzymes present in the cell wall of mycelia. The overall peaks from FT-IR observation confirm the presence of protein in the samples of silver nanoparticles. It can be assumed that nitrate reducing plant leaf provides nitrate reductase enzyme (protein). The silver ions were reduced in the presence of nitrate reductase, leading to the formation of silver nanoparticles and stabilized by capping peptide.

\section{XRD analysis}

The XRD pattern of synthesized silver nanoparticles using $A$. indicum (L.) Sweet leaf extract was recorded and typical XRD pattern is shown (Fig. 4). The peaks are indexed as $2 \theta$ positions, 10.0884 and 14.6254 plans of silver by comparing with JCPDS data. Apart from these peaks responsible for silver nanoparticles, the recorded XRD pattern shows
Fig. 4 XRD pattern of silver nanoparticles

Fig. 5 Screening of antibacterial activity

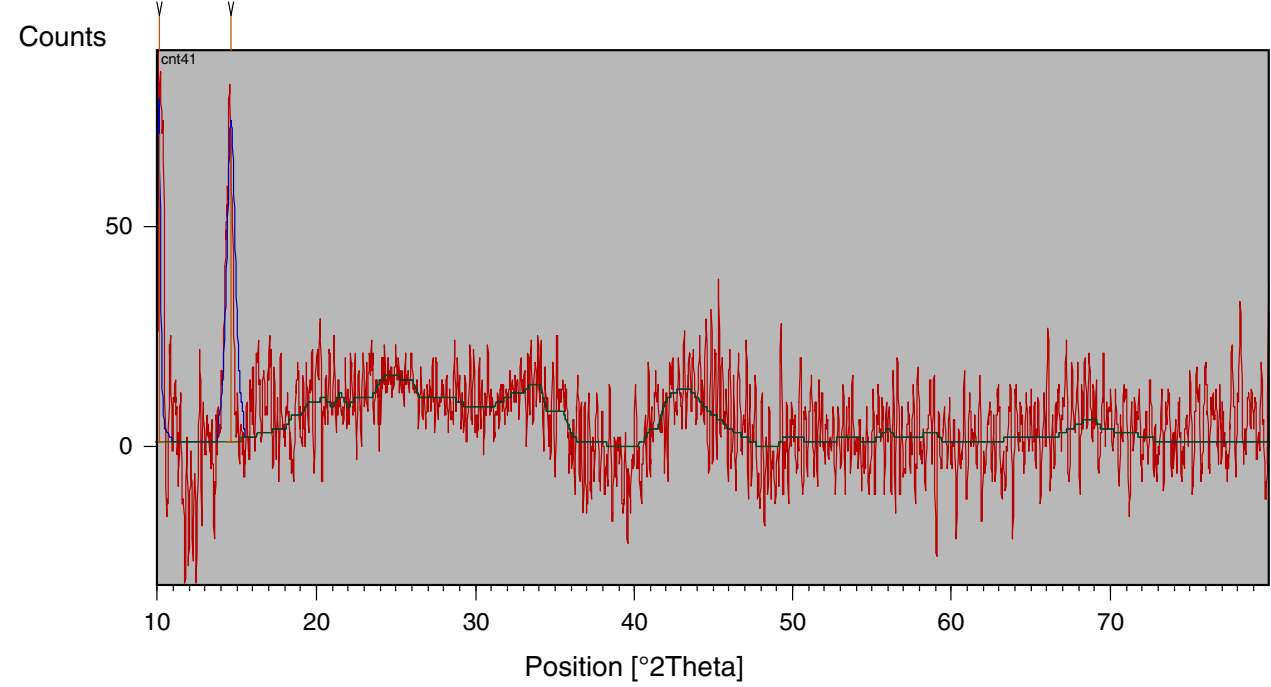

Anti-Bacterial Activity against Pathogenic Micro organisms by using synthesis of Silver nanoparticles
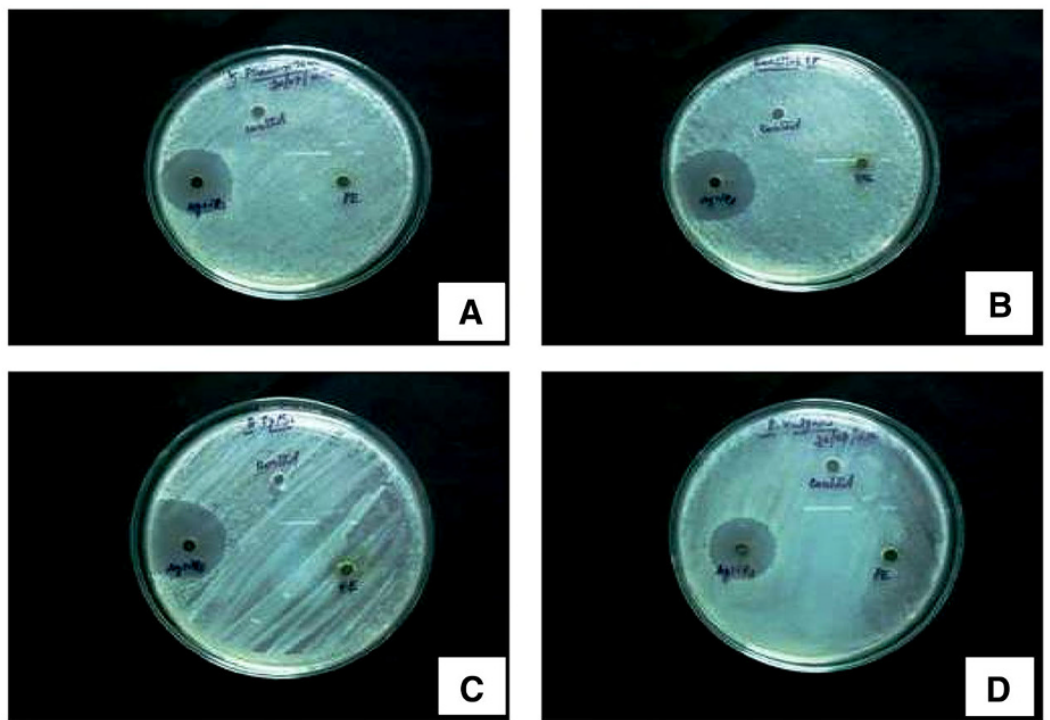

A. Klebsiella pneumoniae B. Bacillus subtilis

C. Salmonella typhi

D. Protens vulgaris 
Table 1 Anti-bacterial activity against different pathogenic bacterial strains

\begin{tabular}{ll}
\hline Bacterial strains & Zone of inhibition $(\mathrm{mm})$ \\
\hline Klebsiella pneumonia & $23.00 \pm 0.57$ \\
Bacillus subtilis & $26.67 \pm 0.88$ \\
Salmonella typhi & $\mathbf{3 2 . 0 0} \pm \mathbf{1 . 2 0}$ \\
Proteus vulgaris & $22.67 \pm 0.60$ \\
\hline
\end{tabular}

Bold values indicate the highest zone of inhibition \pm standard error

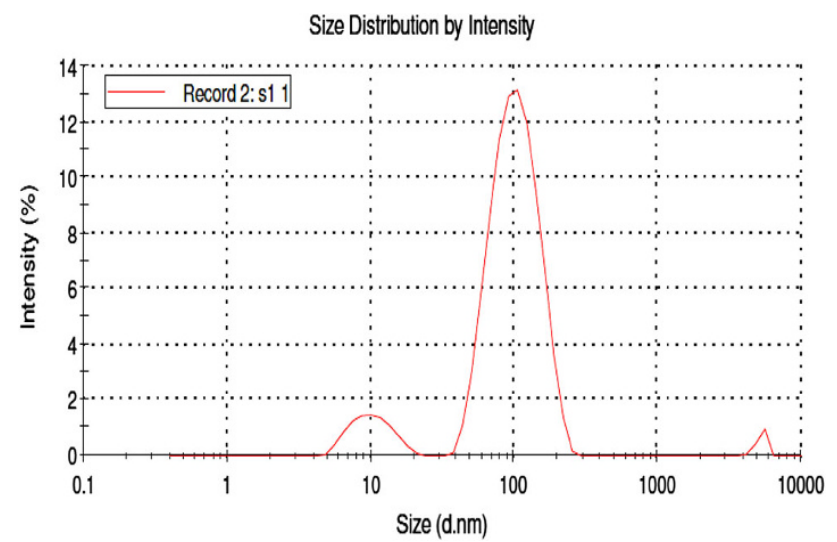

Fig. 6 Particle size analysis

additional unassigned peaks. This may due to the formation of the crystalline bio-organic compounds/metallo proteins that are present in the A. indicum (L.) Sweet leaf broth. Similar observations were reported for the silver nanoparticles synthesized using $P$. graveolens leaf extract [29]. The detailed investigation on this crystalline phase existing with the silver nanocrystals is in progress.

\section{Anti-bacterial activity}

The anti-bacterial activity of silver nanoparticles is reported to a large extent. The silver nanoparticles are synthesized and also show anti-bacterial activity against four strains of laboratory pathogens viz. Klebsiella pneumoniae, Proteus vulgaris, Salmonella typhi, and Bacillus subtilis (Fig. 5). The zone of inhibition measured is summarized in Table 1. From the table, it is proved that the nanoparticles synthesized are good candidates their usage as and/or in anti-bacterial drugs. Each experiment was performed for three times. The data shown represent the mean $\pm \mathrm{SE}$. The data were analyzed statistically using SPSS (version-16) software.

Particle size analysis

The particles size analysis of silver nanoparticles of $A$. indicum (L.) Sweet (Fig. 6). The sizes of particle in diameter $106 \mathrm{~nm}$ were noticed.

\section{Conclusion}

We have prepared silver nanoparticles using leaf extracts of Abutilon indicum L. Sweet, a plant abundantly found in Asia, as reducing agent. A. indicum (L.) Sweet has more medicinal properties, especially in anti-microbial activity. The above plant source involved nitrate reduction with help of nitrate reductase. This plant material released extracellular protein molecules. It acts as template for the silver nucleation sites for the formation of nanocrystals. FT-IR reveals that protein molecules can be bound to nanoparticles and XRD result confirmed silver crystal structure. The plant source may act as capping agents (peptides or proteins) which control the size and shape of silver nanoparticles. On the basis of our results, leaf protein molecules play a vital role in reducing and capping of silver nanoparticles.

Open Access This article is distributed under the terms of the Creative Commons Attribution License which permits any use, distribution, and reproduction in any medium, provided the original author(s) and the source are credited.

\section{References}

1. Bar, H., Bhui, D.K., Sahoo, G.P., Sarkar, P., Pyne, S., Misra, A.: Green synthesis of silver nanoparticles using seed extract of Jatropha curcas. Colloids Surf. A 348(1-3), 212-216 (2009)

2. Narayanan, K.B., Sakthivel, N.: Coriander leaf mediated biosynthesis of gold nanoparticles. Mater. Lett. 62(30), 4588-4590 (2008)

3. Paulkumar, K., Gnanajobitha, G., Vanaja, M., Rajeshkumar, S., Malarkodi, C., Pandian, K., Annadurai, D.: Piper nigrum leaf and stem assisted green synthesis of silver nanoparticles and evaluation of its antibacterial activity against agricultural plant pathogens. Sci. World J. 1-9 (2014)

4. Sathishkumar, M., Sneha, K., Won, S.W., Cho, C.-W., Kim, S., Yun, Y.-S.: Cinnamon zeylanicum bark extract and powder mediated green synthesis of nano-crystalline silver particles and its bactericidal activity. Colloids Surf. B 73-2, 332-338 (2009)

5. Daisy, P., Saipriya, K.: Biochemical analysis of Cassia fistula aqueous extract and phytochemically synthesized gold nanoparticles as hypoglycemic treatment for diabetes mellitus. Int. J. Nanomed. 7, 1189-1202 (2012)

6. Ankamwar, B., Damle, C., Ahmad, A., Sastry, M.: Biosynthesis of gold and silver nanoparticles using Emblica officinalis fruit extract, their phase transfer and transmetallation in an organic solution. J. Nanosci. Nanotech. 5(10), 1665-1671 (2005)

7. Krishnaraj, C., Jagan, E.G., Rajasekar, S., Selvakumar, P., Kalaichelvan, P.T., Mohan, N.: Synthesis of silver nanoparticles using Acalypha indica leaf extracts and its antibacterial activity against water borne pathogens. Colloids Surf. B 76(1), 50-56 (2010)

8. Jo, Y.-K., Kim, B.H., Jung, G.: Antifungal activity of silver ions and nanoparticles on phytopathogenic fungi. Plant Dis. 93(10), 1037-1043 (2009)

9. Asra-Parveen, Aashis S Roy, Srinath-Rao, : Biosynthesis and characterization of silver nanoparticles from Cassia auriculata leaf extract and in vitro evaluation of antimicrobial activity. J. Appl. Biol. Pharm. Tech. 3, 222-228 (2012)

10. Duncan, T.V.: Applications of nanotechnology in food packaging and food safety: barrier materials, antimicrobials and sensors. J. Colloid Interface Sci. 363(1), 1-24 (2011) 
11. Mohammed Fayaz, A., Balaji, K., Girilal, M., Kalaichelvan, P.T., Venkatesan, R.: Mycobased synthesis of silver nanoparticles and their incorporation into sodium alginate films for vegetable and fruit preservation. J. Agric. Food 57(14), 6246-6252 (2009)

12. Kokura, S., Handa, O., Takagi, T., Ishikawa, T., Naito, Y., Yoshikawa, T.: Silver nanoparticles as a safe preservative for use in cosmetics. Nanomedicine 6(4), 570-574 (2010)

13. Singh, M., Singh, S., Prasad, S., Gambhir, I.S.: Nanotechnology in medicine and antibacterial effect of silver nanoparticles. Dig. J. Nanomat. Biostruct. 3(3), 115-122 (2008)

14. Ravishankar, B., Sharanabasava, G., Raghunandan, D., Venkataraman, A., Ravindra, G.: Rapid biosynthesis of silver nanoparticles using areca nut (Areca catechu) extract under microwave-assistance. J. Clust. Sci. 24, 107-114 (2013)

15. Tripathi, A., Chandrasekaran, N., Raichur, A.M., Mukherjee, A.: Antibacterial applications of silver nanoparticles synthesized by aqueous extract of Azadirachta indica (neem) leaves. J. Biomed. Nanotechnol. 5(1), 93-98 (2009)

16. Vivekanandhan, S., Misra, M., Mohanty, A.K.: Biological synthesis of silver nanoparticles using Glycine max (soybean) leaf extract: an investigation on different soybean varieties. J. Nanosci. Nanotechnol. 9(12), 6828-6833 (2009)

17. Sathishkumar, M., Sneha, K., Won, S.W., Cho, C.W., Kim, S., Yun, Y.S.: Cinnamon zeylanicum bark extract and powder mediated green synthesis of nano-crystalline silver particles and its bactericidal activity. Colloids Surf. B Biointerfaces 73(2), 332-338 (2009)

18. Begum, N.A., Mondal, S., Basu, S., Laskar, R.A., Mandal, D.: Biogenic synthesis of $\mathrm{Au}$ and $\mathrm{Ag}$ nanoparticles using aqueous solutions of black tea leaf extracts. Colloids Surf. B Biointerfaces 71(1), 113-118 (2009)

19. Naheed-Ahmad, Seema-Sharma, Radheshyam-Rai, : Rapid green synthesis of silver and gold nanoparticles using peels of Punica granatum VBRI. Adv. Mater. (2012). doi:10.5185/amlett.2012. 5357
20. Shameli, K., Bin Ahmad, M., Jaffar A-Mulla, E.A., Ibrahim, N.A., Shabanzadeh, P., Rustaiyan, A., Abdollahi, Y., Bagheri, S., Abdolmohammadi, S., Usman, M.S., Zidan, M.: Green biosynthesis of silver nanoparticles using Callicarpa maingayi stem bark extraction. Molecules 17, 8506-8517 (2012)

21. Jiang, H., Manolache, S., Wong, A.C.L., Denes, F.S.: Plasma enhanced deposition of silver nanoparticles onto polymer and metal surfaces for the generation of antimicrobial characteristics. J. Appl. Polym. Sci. 93, 1411-1422 (2004)

22. Kim, K.J., Sung, W.S., Suh, B.K., Moon, S.K., Choi, J.S., Kim, J.G., Lee, D.: Antifungal activity and mode of action of silver nanoparticles on Candida albicans. Biometals 22(2), 235-242 (2009)

23. Nadworny, P.L., Wan, G.J., Tredget, E.E., Burrell, R.E.: Antiinflammatory activity of nanocrystalline silver in a porcine contact dermatitis model. Nanomedicine 4(3), 241-251 (2008)

24. Rogers, J.V., Parkinson, C.V., Choi, Y.W., Speshock, J.L., Hussai, S.M.: A preliminary assessment of silver nanoparticle inhibition of monkey pox virus plaque formation. Nanoscale Res. Lett. 3, 129-133 (2008)

25. Song, J.Y., Kim, B.S.: Rapid biological synthesis of silver nanoparticles using plant leaf extracts. Bioprocess Biosyst. Eng. 32, 79-84 (2009)

26. Kelly, K.L., Coronado, E., Zhao, L.L., Schatz, G.C.: The optical properties of metal nanoparticles: the influence of size, shape and dielectric environment. J. Phys. Chem. B 107, 668-677 (2003)

27. Stepanov, A.L.: Optical properties of metal nanoparticles synthesized in a polymer by ion implantation: a review. Tech. Phys. 49, 143-153 (1997)

28. Shameli, K., Ahmad, M.B., Jazayeri, S.D.: Investigation of antibacterial properties silver nanoparticles prepared via green method. Chem. Cent. J. 6, 73 (2012)

29. Shiv Shankar, S., Rai, A., Ahmad, A.: Rapid synthesis of Au, Ag, and bimetallic $\mathrm{Au}$ core-Ag shell nanoparticles using Neem (Azadirachta indica) leaf broth. J. Colloid Interface Sci. 275(2), 496-502 (2004) 